\title{
Meeting urges scientists into politics
}

Scientists who think the world would be a better place if more of their sort held public office are being urged to help make the changes they want and offered advice on how to do so.

On 10 May, the non-partisan organization Scientists and Engineers for America (SEA) held a workshop in Washington DC to tell scientists what it takes to run for public office - and how to go about it. Around 75 scientists, science teachers, science-policy experts and other interested parties gathered on the campus of Georgetown University to explore the transition from scientist to politician. Some were aspiring politicians. Others hoped to contribute to the inner workings of political campaigns. All of them learned how difficult it is to translate a scientific career into a leadership role in politics.

Early insight came from Kevan Chapman, the communications director for Vernon Ehlers - a physicist and Republican who represents a portion of Michigan. As a political candidate, Ehlers has always touted his scientific background. During his 15 years in Congress, he has emphasized that the greatest asset of his scientific training is his reasoned, rational way of approaching complex problems.

Playing up a training in rational thinking could be a greater benefit in the political arena now than in the past, says Joe Trippi, architect of the innovative online fund-raising effort that fuelled Howard Dean's 2004 campaign for the Democratic presidential nomination. American citizens, Trippi says, are ready for an end to "transactional politics", of the "Vote for me, and I'll cut your taxes' approach. "No

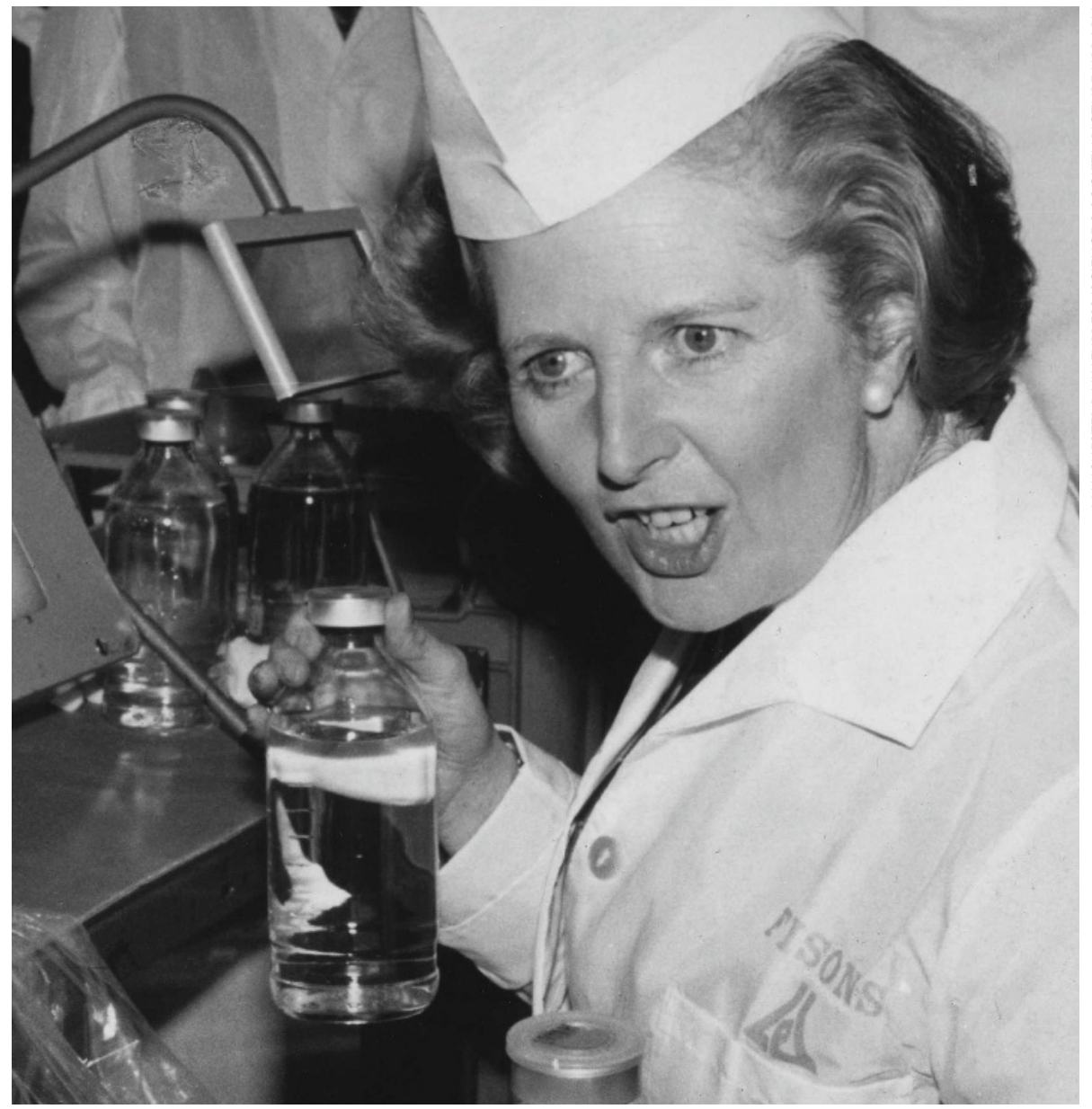

For chemists to get to the top, like this one did, is rare. deal in the world," explains Trippi, will bring about an end to global warming, so scientists-turned-politicians should underscore that they have been trained to find solutions, not to trade vacuous political barbs with the opposition.

Sarah Mullins, a chemist at 3M in St Paul, Minnesota, who helps the American Chemical Society to lobby Congress, found Trippi's remarks energizing. "He actually put out a vision of scientists in electoral politics," she said. "It just

of establishing oneself in the community can be challenging for scientists whose schedules are often inflexible and who move frequently, especially early in their career.

"It is best to clear your plate and focus on running for office," says Louis Lanzerotti, a physicist and member of the National Science Board who also served as mayor of Harding Township in New Jersey. Lanzerotti says he is often asked for scientific advice out of his field; recently, as a consultant on one wasn't the same old 'we need people to be good leaders." Mullins has no plans to run for office right now, but she intends to use Trippi's comments to try to convince fellow chemists that they can have an important role in politics.

Still, would-be candidates face numerous practical considerations. The time commitment involved and the importance project, he calculated the costs and benefits of artificial athletics fields, and the possibility of turf-associated chemicals leaching into nearby streams.

Speaker David Westerling, a civil engineer, agrees that local issues are important, saying that he had his first success by looking at community projects such as drainage, wetlands and athletics facilities. Westerling told the participants to think about how they could take advantage of their academic contacts, although with caution. Westerling himself experienced a backlash when trying to raise money for his first campaign via his alumni association.

Indeed, some might find that scientist colleagues frown on their political aspirations. Physicist Michael Lubell, director of the American Physical Society in Washington DC, says that his Yale colleagues were puzzled when he started canvassing for votes for the successful Lyndon B. Johnson presidential campaign as a graduate student in 1964. "But," he said, smiling, they "eventually recognized that I had political contacts they could take advantage of".

In July, the SEA plans to start an online advice forum for scientists interested in running for office.

Gene Russo 